\title{
INTRODUCTION TO THE ENGLISH-LANGUAGE EDITION
}

\author{
ROBIN KINROSS
}

Significant literary work can only come into being in a strict alternation between action and writing: it must nurture the inconspicuous forms that better fit its influence in active communities than does the pretentious, universal gesture of the book - in leaflets, brochures, articles, and posters. Only this prompt language shows itself actively equal to the moment. Opinions are to the vast apparatus of social existence what oil is to machines: one does not go up to a turbine and pour machine oil over it; one applies a little to hidden spindles and joints that one has to know.

Die neue Typographie was published in Berlin in June 1928. The author was the then twenty-six-year-old German typographer Jan Tschichold. The publishers were the Bildungsverband der Deutschen Buchdrucker: the educational association of the German printing-trade union. The book was the most detailed and best-illustrated exposition of the New Typography. This was the manifestation in the sphere of printed communication of the modern movement in art, in design, and - at least this was its aspiration - in life as a whole, which developed in Central Europe between the two world wars. To take representative or iconic instances, one could mention the new architecture built for the city of Frankfurt (under the direction of Ernst May), the political theatre of Bertolt Brecht and Hanns Eisler, the tubularsteel furniture of Mart Stam or Marcel Breuer, the cinema of Dziga-Vertov or Joris Ivens, journals such as 110 or Die Form: work in which formal innovation and social concerns were intertwined. The New Typography now falls into place in the constellation of Central European modernist culture. Tschichold's book remains unsurpassed as the best single document of and about the New Typography. But its context and concerns now need considerable explanation.

\section{TSCHICHOLD BEFORE DIE NEUE TYPOGRAPHIE}

Jan Tschichold (1902-1974) was the son of a Leipzig sign-writer and lettering artist. ${ }^{1}$ His early start in - and lifelong preoccupation with - lettering and typography is thus not surprising. Leipzig was one of the centres for printing and publishing in Germany, and at the heart of the country's typographic culture. After an informal apprenticeship to his father, he 
attended classes at the Akademie für Künste und Buchgewerbe [academy of art and of the book trade] in Leipzig (from 1919) and then (from 1921) at the Kunstgewerbeschule [school of arts and crafts] at Dresden. In 1921 he also started to teach an evening class in calligraphy at the Leipzig Akademie.

In the early 1920s Tschichold worked primarily as a calligrapher, writing out texts for printed reproduction. Small advertisements for the Leipzig trade fairs were a staple job. The design approach of this early work can be called traditional, although it seems to show a rather eclectic experimentation with different letterforms and styles of writing.

In Tschichold's own account, two turning-points for him came in 1923. First, he began to practice "the previously unknown profession of typographic designer" with the large Leipzig printing firm of Fischer \& Wittig. ${ }^{2}$ The characteristic, defining activity of the typographic designer was the instruction of compositors by precisely drawn and dimensioned layouts. Previously the process of setting type had not been formally directed. except perhaps by vague sketches drawn by compositors themselves (or their senior colleagues). or occasionally (since perhaps the end of the nineteenth century) by the figure that Tschichold refers to, in quotation marks, as the "book-artist." 3

The second turning-point was Tschichold's conversion to modernism, which he dated from his visit to the exhibition of the Weimar Bauhaus in the summer of 1923. This was the first full presentation of work done at the Bauhaus, held just at the point when the school was turning from its initial handicrafts phase towards a more technically oriented program and an engagement with the conditions of industrial production. The experience of visiting this exhibition touched Tschichold at the deepest level. ${ }^{4}$ The first clearly modern works by Tschichold that have been reproduced are dated to 1924: a poster for the Philobiblon publishing house in Warsaw, a letterheading for Nina Khmelova in Moscow. Before this, in 1922 or 1923, he is reported to have made the acquaintance of László Moholy-Nagy, who in turn introduced him to El Lissitzky: the two artist-designers whose work most encouraged his turn. 5 And a significant indicator in this process of change was his adoption, around 1923/24, of the name "Iwan Tschichold." His given name had been Johannes Tzschichhold: his father, and mother also, had Slav origins. Throughout his working life Tschichold tended to look East - he became an authority on Chinese and Japanese prints - but at that point in the mid-1920s, this perhaps ancestral inclination took on a particular ideological charge. "Iwan" proclaimed his new allegiance to the social-artistic ideas of the Russian Constructivists. 
Tschichold's first published statement came in October 1925, in a special issue of the journal Typographische Mitteilungen, entitled elementare typographie. ${ }^{8}$ This was the journal of the Bildungsverband der Deutschen Buchdrucker (then published in Leipzig), and in having the same publisher and in its character as an anthology of the movement, this document prepared the way for Die neue Typographie. ${ }^{2}$ Even more clearly than the later book, elementare typographie represented an implant of foreign ideas into the settled world of the German printing trade. Among the texts included were a manifesto of Russian Constructivism (a version of the document known as "the program of the Productivist group" of 1920), Moholy-Nagy on "typo-photo," and statements by El Lissitzky. Work by Lissitzky. MoholyNagy. Max Burchartz. Kurt Schwitters, and Herbert Bayer was among the illustrations. Tschichold contributed two texts: "Die neue Gestaltung." a cultural-historical introduction on the lines of the section on "The new art" in the present book; and the manifesto elementare typographie. The publication is rounded off by lists of useful addresses, a bibliography, and editorial commentary, all done with an attention to detail and to the provision of useful information that would become characteristic of Tschichold.

Here, as subsequently. Tschichold's distinction was to mediate complex ideas, and to express them in clear, detailed formulations. If Lissitzky and Moholy-Nagy (to take the two main proponents) were artistic visionaries, Tschichold was the lucid practitioner, able to formulate and develop these visions in the ordinary world. Where they lacked the ability to specify exactly configurations of type and image, and were thus at the mercy of often insensitive printers. Tschichold knew what he wanted and could get it. (The free graphic work of these and similar artists is another matter.) In the issues of Typographische Mitteilungen that followed elementare typographie, and elsewhere in the trade press, a good deal of argument about these ideas was published. ${ }^{10}$ From around this time, the themes of the New Typography, and work done in its spirit, began to be a factor of some significance in German printing. For a few years in Germany, and in Central Europe more generally, there was some economic and material prosperity that could provide a base for this work: say, between the influx of US finance into Germany under the Dawes Plan (1924) and the crisis triggered by the world economic crash of 1929. If the immediate postwar years had been a time of material desolation and of utopian dreams of a new world, there was now the chance of developing and realizing the project of the modern movement.

Tschichold's own work and life developed, in tune with this larger pattern, in these years. In 1926 he married Edith Kramer and moved to Berlin, work- 
ing as a freelance designer. In the summer of that year he moved again, to Munich, to take up a post as teacher at the Meisterschule für Deutschlands Buchdrucker [advanced-level college for German printers]. This institution was then in the process of being established, under the direction of Paul Renner, to provide a more advanced education for printers (there was already a college for the profession - the Graphische Berufsschule [vocational college for the graphic industries] - in Munich). This position would seem to have been an ideal one for Tschichold. It gave him a secure financial basis (evidently it was not possible for him to live on freelance work. especially now that he was married and, from 1929, the father of a son). It enabled him to develop his particular talent of explaining design principles to printers. And it put him in touch with other gifted colleagues, among them: Renner, who was then working on his Futura typeface; Georg Trump. the graphic designer, calligrapher, and typeface designer; and the graphic artist Hermann Virl. 11

\section{DIE NEUE TYPOGRAPHIE}

Tschichold was working on the ideas and material published in Die neue Typographie certainly from late in 1926. In January 1927. Typographische Mitteilungen published a report of a lecture that he gave to the Munich group of the Bildungsverband der Deutschen Buchdrucker. ${ }^{12}$ In May 1927 Tschichold gave a lecture on "Die neue Typographie," also under the auspices of the Bildungsverband, at the Graphische Berufsschule at Munich. A small notice advertising the lecture - which is reproduced here, as a good sample of Tschichold's typography at this stage - is revealing in the precision of its description: "the lecture will be accompanied by over a hundred slides, for the most part in more than one colour, and there will be no discussion afterwards." The last clause seems to say something about the firmness of Tschichold's views. ${ }^{13}$

In August 1927. Tschichold wrote to Piet Zwart that "a book by me about 'the new typography' will appear soon." 14 But it was not until summer of the following year that the book was printed and officially published. The imprint of the book gives the date as "June 1928" (and the number of copies printed as 5,000). As the publicity leaflet - reproduced here - indicates, the price was 6.50 Marks, or 5.00 Marks if ordered from the publishers before 1 June. This price would seem to have been quite modest for a heavily illustrated, cloth-cased book. ${ }^{15}$

The reception of Die neue Typographie appears to have been quiet. Typographische Mitteilungen carried almost no discussion of it, and published very little advertising for the book, in contrast to the debate that fol- 


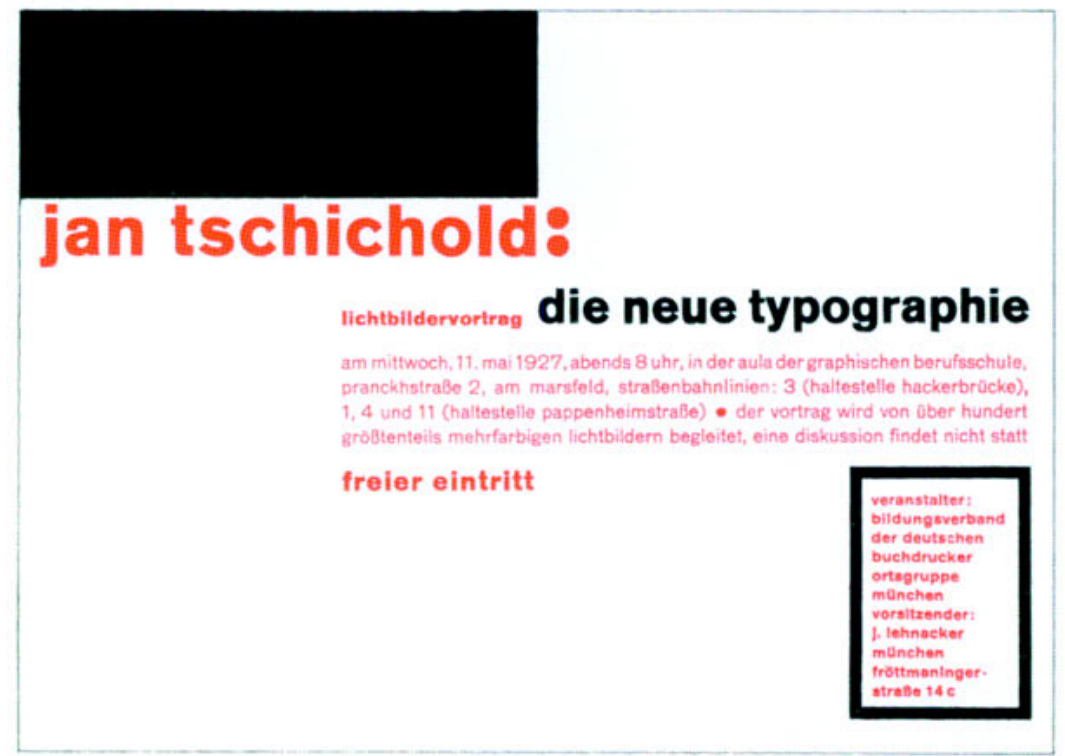

Advertisement for a lecture by Tschichold in 1927.

lowed the publication of elementare typographie. Some reviews can be found in other journals, and these include some perceptive observations that will be taken up again when the themes of the book are discussed. ${ }^{16}$ As to the sales of the book, there is some record of this in the lists of previous publications by the author, which Tschichold provided, with typical exactness, in subsequent books. In 1930, Die neue Typographie was described as "almost out of print": and in 1931, as "out of print" without qualification. ${ }^{\mathbf{1 7}}$ In these terms, the book was clearly a success. And already early in 1929. Tschichold reported to Piet Zwart that he was working on a new edition. ${ }^{18}$ Eighteen months later, this was announced as "coming out soon," and Tschichold requested material from Zwart - as presumably from other colleagues - for illustration. ${ }^{19}$ The book was going to be "quite changed": for example it would have a larger (A4) format. Later, in 1932. Tschichold told Zwart that although the text for the second edition was ready for setting. the publishers did not want to undertake the risk of proceeding with this, in view of unfavourable conditions. ${ }^{20} \mathrm{He}$ added that the Russian edition might come out before this second German edition. 
Another letter of September 1932 - from Lissitzky to Tschichold - asked, "What are the prospects for the new edition of the big book about new typography?" 21

Economically and politically, prospects for radical modernism in Germany were then very bad. Almost 30 per cent of the working population was unemployed (the figure had been 6 per cent in 1928). Everyday life was increasingly politicized, and German politics became increasingly violent and extreme. In the elections of July 1932, the National Socialists more than doubled their representation in parliament, taking 37 per cent of the vote. In further elections in November of that year, the Nazi vote dropped: a factor that only increased their determination to take power by any means. The parties that might together have defeated right-wing reaction the SPD [social-democratic party] and the KPD [communist party] - were irrevocably opposed to each other. In January 1933. Adolf Hitler was appointed Chancellor of Germany, and the National Socialist party seized power. The elections of March, held under less than free conditions, confirmed National Socialist power, and gave a semblance of legitimacy to the rapid dismantling of the fragile democratic structure of the Weimar Republic. Freedom of expression had been lost. It goes without saying that a second edition of Die neue Typographie was out of the question. ${ }^{22}$

\section{THEMES OF THE BOOK}

As its contents page indicates, Die neue Typographie is made up of two parts: a historical and theoretical discussion of the "growth and nature" of the movement; and detailed consideration of the "principal typographic categories," with reference to particular examples. These different parts have in common a pedagogic character: this is a "handbook," and Tschichold is bringing knowledge to printers (in the first place) and to anyone who might take a special interest in typographic communication.

The opening pages of the book put forward the social and philosophical grounds for the new typography. The ideas and the language that Tschichold uses here are those that inform modernist texts of the period: the manifestos and proclamations of the various groups and movements. many of which are listed in the book's impressively detailed bibliography (pp. 229-235). ${ }^{23}$ Life has changed, it is mechanized, urban, faster; emphasis is now on the social, the collective, rather than the individual; on the impersonal and factual, rather than the romantically indefinite; human liberation can come through the standardization of material artefacts, through 


\section{VORZUGS-ANGEBOT}

Im VERLAG DES BILDUNGSVERAANDES der Deutachen Buehdrucker, Berlin SW 61, Dreibundstr, 5, erscheint demnachst:

\section{JAN TSCHICHOLD}

Lehrer an der Meisterschule for Deutschlands Buchdrucker in Manchen

\section{DIE NEUE TYPOGRAPHIE}

\section{Handbuch für die gesamte Fachwelt}

und die drucksachenverbrauchenden Kreise

Das Problem der neven gentaitenden Typographio hat eine lethafte Diskussion bel allen Beteiligten hervorgerufen, Wir glauhen dem Bedbrt. nis, die aufgeworfenen Fragen ausfuhrlich behandelt zu seben, zu ent. sprechen, wenn wir jetzt ein Handbuch der NEUEN TYPOGRAPHIE heraushringen.

Es kam dem Verfasser, einem threr bekanntesten Vertreter, in dieserm Buche zunlichst daraut an, den engen Zusammenhang der nouen Typographie mit dem Gesamtkomplex heutigen Lebens aufruzel. gen und tu beweisen, dab die neue Typographie ein ebenso notwendi. ger Ausdruck einer neuen Gesinnung ist wie die neue Baukunst und alles Neute, das mit unserer Zeit anbricht. Diese geschichtiche Notwen. digkeit der neues Typographie belegt weiterhin eine kritische Darstellung der alten Typographie. Die Entwicklung der neuen Malerei, die fur aties Neue unserer Zeit geistig bahnbrechend gewesen ist, wird in einem reich illustrierten A fufutr des Buches leicht fabtich dat. Wisesteil Fin hurzer Abechnith Zur Geschichte der newen Typegragestech tin burzer Abach hith, Zur Goschichte der neven TypograBuchess den Grundbegriffen der neuen Typographie uber. Diese werden kar hernusgeschalt, richtige und falsche Beispiele einander gegenubergestellt. Zwei we tere Artikel behandein Photographie und Typographie" und Neue Typographie und Normung

Der Hauptwert des Buches fur den Praktiker besteht in dem zweiten Tril Typographische Haupttormen " (siehe das nebenstehende Teli "Typographische Hauptrormen " Wieho das nebenstehende Inhaltsverzeichnia), Eatehite biaher an einem Werke, das wiedleses Buch Fragen in gebuhrender Ausfohrichkeit behandelte, Jeder Teilabschnitt enthast neben allgemeinen typographischen Regein vor allem die Abbildungen aller in Betracht kommenden Normblätter des Deutschen Normenausschusses, alle andern (2. B. postalischen) Vorschriften und zahireiche Beisplele, Gegenbelispiele und Schemen.

Fur Jeden Buchdrucker, Insbesondere jeden Akzidenzsetzer, wird „Die neve Typographie" ein unentbehrliches Handbuch sein. Von nich neringerer Bedeufung ist es for Reklamefachleute, Gebrauchsgraphiker, Kaufieute, Photographen, Architekten, Ingenieure und Schriftsteller, also for alle, die milt dem Buchdruck in Berohrung kommen.

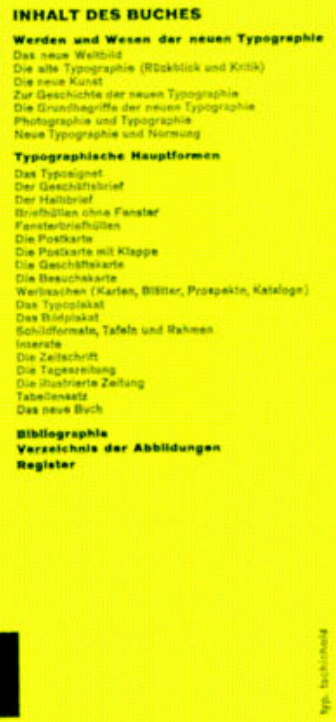

Das Buch enthalt ober 125 Abbildungen, von denen etwa ein Viertel zweifarbig gedruckt ist, und umfast gegen 200 seiten auf gutem Kunstdruckpapier, Es erscheint im Format DIN A 5 (148) $210 \mathrm{~mm}$ ) und ist biegsam in Ganzleinen gebunden.

Preis bei Vorbestellung bis 1. Juni 1928:

5.00 RM durch den Buchhandel nur zum Preise von

6.50 RM

Bestellschein umstehend

Publicity leaflet for Die neue Typographie. 
equality of provision: no longer the artist and the privileged sensibility, but the engineer and the ordinary citizen.

If Tschichold's prose in these opening pages seems excited - especially in the context of a handbook for printers - it is of its time. One could argue that it is actually a few years behind the leading formulations. For example. Tschichold's play with the figure of "the engineer" - which he sets in bold type, at a crucial rhetorical moment (p. 11) - is clearly in the same spirit as Le Corbusier's rhapsodic argument in Vers une architecture, first published in book form in 1923:

Not in pursuit of an architectural idea, but simply guided by the results of calculation (derived from the principles which govern our universe) and the conception of a living organism, the engineers of to-day make use of the primary elements and, by co-ordinating them in accordance with the rules, provoke in us architectural emotions and thus make the work of man ring in unison with universal order. ${ }^{24}$

And this is also the spirit of Tschichold's references to automobiles, telephones, electric light-bulbs, boxers, and other icons of the modern age. Tschichold's argument here gains particular force and authenticity, because in his publisher (the Bildungsverband) and its readership of printers, he was directly in touch with real "engineers." And for internal evidence of this contact, one could cite the beautiful detail on page 122, where he advises that numbers indicating fold-marks on a letter-heading should be made from brass (rather than the normal predominantly lead alloy), because, standing isolated in the margin of the sheet, they are subject to greater pressure and wear. As already noted. Tschichold treats the artist-designer with considerable disdain. In his account of "the old typography (1450-1914)," the artistic and decorative approach is only excused as perhaps valid in its day. Those who still try to practice such an approach in the modern world - the "book artists," for example - are condemned as out of touch with the new age and are thus mere formalists:

But the difference between these modern works and their classical models is that the models really are an expression of their time. whereas the imitations are the expression of a highly sensitive eclecticism, which is an attitude foreign to the present day, looking for its ideal in another time and world. (P. 25)

Tschichold's arguments may employ the terms of use. need, and function, but they are deeply and explicitly infused with the idea that form must be created and that it must be the form of the new age. In this he was 
absolutely typical as a theorist of modernism. The paradox in the argument lies in the wish for self-effacing, abstract form. A characteristic statement of position might be quoted from a few pages further on:

Individualistic work, the "line" of the artist, are the exact opposite of what we are trying to achieve. Only anonymity in the elements we use and the application of laws transcending self combined with the giving up of personal vanity (up till now falsely called "personality") in favour of pure design assures the emergence of a general, collective culture which will encompass all expressions of life - including typography. (Pp. 28-29)

The political dimension of this view becomes more evident in the section that deals with "the new art" (pp. 30-51). Borrowing quite frequently from the language of Marxism, as then popularly disseminated, Tschichold discusses the history of art in terms of social class and technical development. (The atmosphere of a workers' education lecture is further recalled by his conscientious footnote translations of foreign terms.) Historical development, as he outlines it, points ineluctably to abstract art (perhaps dissolved into the forms of everyday life, as architecture and industrial design) and to photography and film.

In these passages, the intimate association between modernism in design and socialist politics is clear - or, at least, the connection was clear at that time and in that place. Both strands combined into a single outlook that might typically be termed "progressive." Tschichold was here writing for a trade-union-associated publisher, and his design work at this time included work for socialist - or socially oriented - publishers and other clients. ${ }^{25}$ Tschichold's Marxist rhetoric was made fun of in a review of the book published in bauhaus, the journal of the school, which was then (under Hannes Meyer) at its most committed to the socialist-materialist position. ${ }^{26}$ After quoting Tschichoid's suggestion that borders around the printing area of a large advertisement are "a characteristic expression of the earlier individualistic epoch" (p. 199), the anonymous reviewer remarked that in order to combat individualism one needs to address not just the appearance of advertisements but the very existence of such advertising. In this reviewer's account. Tschichold's book discussed and illustrated only formal matters, and ended up by proposing no more than a new formalism, which its author mistook for a new conception of the world. Whether or not that judgment of Tschichold as a "formalist" was just, there was certainly some point in the objection to his appropriation of the language of political change in the discussion of typographic detail. 


\section{THE NEW TYPOGRAPHY}

The New Typography - as a term, as a movement - is given some explanation by Tschichold in the first half of this book. As he makes clear, it was a collective endeavour, which was finding definition step by step. Lászió Moholy-Nagy's article entitled "Die neue Typographie" - appearing in the publication that accompanied the Bauhaus exhibition of 1923 - would have helped to establish the term, as well as formulating its leading ideas at a relatively early moment. Tschichold cites this text in his outline of the history of the New Typography (p. 58), but, as his discussion suggests, it was only one of a series of articles and publications of a movement that was just then (in 1928) gathering momentum.

One might see Tschichold's book as standing at the point when the New Typography movement had just taken off, after quite a lengthy journey along the runways. There was enough work for him to reproduce as illustration in the book, but it was of variable quality, and - we can say now there would be work to come that would make many of the things illustrated here look "early."

A good indication of the state of this movement is the history of the semiformal association of artists and designers working in the spirit of the New Typography: this was the Ring "neue werbegestalter." 27 Evidently following the example of the "Ring" of modern architects in Germany (established in Berlin around 1925), this was a loose group of like-minded practitioners, instigated and coordinated by Kurt Schwitters. The Ring "neue werbegestalter" came into existence towards the end of 1927, and became publicly evident early in 1928, with nine founding members: Willi Baumeister, Max Burchartz, Walter Dexel, Cesar Domela, Robert Michel, Kurt Schwitters, Georg Trump, Jan Tschichold, Friedrich VordembergeGildewart. (Other members, joining later, included Piet Zwart, Hans Leistikow. Paul Schuitema.) The Ring can be characterized as a pressure group for New Typography: it came together in exhibitions of work by members and invited guests, discussed and agitated for these and other outlets for work (for example, an international magazine). In the years of its activity (1928 to 1931) over twenty exhibitions were held primarily in German museums, but also in institutions in other countries, including Switzerland and the Netherlands. If one wants to locate the movement of $\mathrm{New}$ Typography, the Ring was the most convincing real embodiment of it: a slightly shaky, intermittent affair, largely held together and fuelled by the enthusiasm of Kurt Schwitters. ${ }^{28}$

The activities of the Ring "neue werbegestalter" were just starting when Tschichold would have been completing Die neue Typographie. In this con- 
nection, one could make some observations that may help an understanding of Tschichold and the present book. First, that in this book he had done as much as any writer could to imagine such a movement into existence. One of the best indications of this is the list of addresses on the last page, which seems to say: here are the protagonists, you have seen their work reproduced in these pages, now write to them! And second, the history of the Ring shows that Tschichold played a moderately active part in it, but not a leading one. He was a colleague, on a level with the others. Tschichold's distinction - and Die neue Typographie is prime evidence of this - lay in explaining and documenting what the others were doing.

It is worth noting also that the Bauhaus, the institution that has so dominated the history of the modern movement (to the extent of sometimes being taken as synonymous with it), is seen in Die neue Typographie, as in all the literature of the period, as just one of the contributing components: one star in a diverse and spreading constellation of institutions and individuals. The Ring "neue werbegestalter" was another star, if a small and erratic one, and it is interesting to observe the rather wary relationship between the Ring and the Bauhaus: as if the former was felt by its members to be in danger of being gobbled up by the latter. ${ }^{29}$ In the event, none of the Bauhaus teachers became members of the Ring, and they participated in its exhibitions only as guests. On the question of Tschichold's relations with the Bauhaus: there is no record of any substantial contact. This apparent distance may point to Tschichold's capacity as a professional typographer, teaching at a school for printers, and the lack of typographic and printing-trade expertise at the Bauhaus, even at Dessau in the time of its greatest ideological commitment to designing for industrial production. ${ }^{30}$

\section{DESIGN PRINCIPLES}

Although Tschichold himself is clear enough about the principles that inform the New Typography in its approach to designing (see especially "The Principles of the New Typography," pp. 64-86), it may be worth pointing out certain aspects that are assumed or latent within his discussion. First, and as already indicated, it is clear that the New Typography could not, for Tschichold, be a simple matter of aesthetics: this category was always dissolved into a larger and more complex consideration of use and purpose. This is not to say that the New Typography was without an aesthetic or formal dimension: and least of all in the work of Tschichold, which by this time was beginning to display a sure control of subtly chosen and often self-effacing means. In the original edition of Die neue Typographie, good evidence for this lies in the material substance of the book itself. The 
just-flexible boards of the case-binding were covered in fine-grain black cloth. The corners of the case were rounded. These features might have seemed to encourage its use as a "handbook": it might sit happily in the pocket of a printer's workshop jacket. Or one could consider the "frontispiece" to the book: the page facing the title-page. This is simply a black page. Should one regard this in functional terms - as a device to concentrate the reader's attention on the title-page? Or is it a defiant assertion of abstraction, against the figurative or decorative illustration employed in the old typography? Or could one take it more metaphysically - as a statement of the possibility of maximum ink, an extreme of the book's subject of printing?

A fundamental theme of the book, which tends inevitably to be lost in English translation of German texts of this period, is the charge that the word "Gestalt" and its derivations carried. It means "design," but design in a full and complex sense: the process of giving or finding form. (The full sense of the term is clear in Tschichold's one-sentence summary of his approach, quoted on p. xxxvi below.) The matter is further confused by the fact that the word "design" has since become so widely used, even to the extent, in several languages, of displacing native words for the activity. But here, "design" has nothing to do with decoration and the mere making of patterns. The examples that Tschichold reproduces (pp. 83-85) to illustrate a false understanding of modern design make the point with splendid clarity and finality.

Against such false decoration. Tschichold proposes a way of designing that develops "its visible form out of the function of the text" (pp. 66-67). From this assumption come the principles that distinguish the New Typography. and all branches of modern design: asymmetry, the positive deployment of empty space, the meaningful use of colour, the meaningful exploitation of contrast and a corresponding lack of interest in visual balance. Tschichold's discussion (for example, p. 68) recalls a characteristic modernist theme: asymmetry is a principle of freedom, of adaptability. just as the "free plan" of the modern house is a response to new social habits and desires. These ideas were translated into, or used as support for, the characteristic visual vocabulary of the New Typography. As examples one could cite: the use of axes from which to range text and other elements, and the renunciation of axial symmetry; the use of bold type, perhaps (as in this book) in marked contrast to text set in a light weight of type; acceptance of constraints, perhaps in the form of an underlying grid-structure, as a means of bringing order to the material and also of giving freedom to the producers (the diagrams on pp. 210-211 are a classic demonstration of 
this point). Finally, one can notice that nowhere in this book or elsewhere in his theory or practice did Tschichold give any sustained attention to the issue of setting continuous text unjustified or ragged (and with equal word-spaces). It was left to others to explore this seemingly logical extension of the principle of asymmetry. ${ }^{31}$

\section{STANDARDIZATION}

Norms and standards play a fundamental part in the argument of Die neue Typographie, and this may also be the element in the book that now needs most explanation. In the modern movement as a whole, the promise held out by standardization can be briefly summarized: this was a means for bringing order to industrialized societies, for settling some of the fundamental elements of life. Producers, users, and intermediaries would be able to act more freely once these basic factors had been determined. In design. as Tschichold's discussion here recognizes, there were some awkwardnesses and paradoxes. Would not standardization (of paper sizes, or of the layout of business stationery) limit invention and variety? Could standardization embody good design principles?

The standards described in this book are those of the Deutscher Normenausschuss, a body whose history reached back into the nineteenth century. ${ }^{32}$ Initially (since 1850) there had been the Verein Deutscher Ingenieure, which formed a committee on standardization (Normalienausschuss der VDI). During the First World War, the need to mobilize industry for maximally efficient production gave a strong impulse to the standards effort. And the conditions of impoverishment and disorganization in Germany, following defeat in that war, only provided further stimulus. In 1917, the VDI's committee had become the Normenausschuss der Deutschen Industrie, which in 1926 had become the Deutscher Normenausschuss. This genealogy suggests one ground for the attraction that standardization held for modernist designers. This really did seem to be the voice of the engineer, issuing in very exact recommendations for the design of artefacts. Standards seemed to embody a collective wisdom, as against the willful arbitrariness of individual expression.

The standards for printed matter that Tschichold mainly refers to were generated from within a particular sector of interest: the rationalization movement in industry and in office-work. Here one can observe a familiar paradox in the modern movement: a system of beliefs that often encompassed revolutionary socialism and (capitalist) theories of business-efficiency. ${ }^{33}$ The most vivid precedent here was Lenin's espousal for the Soviet Union of a Taylorist approach to industrial organization. The prime mover behind the 
DIN (Deutsche Industrie-Normen) standards for office-work and printing would seem to have been Walter Porstmann, from whose writings Tschichold would have drawn most of his knowledge of the matter. Porstmann had written a doctoral dissertation on measurement systems. and had aiso worked as an assistant to the scientist Wilhelm Ostwald, among whose varied activities was the proposal for paper-size standardization that Tschichold describes in his outline history of the subject (pp. 96-97).34 From at least 1917 and through the 1920s, Porstmann was an active participant in the development of the DIN standards that were of importance to printing and typography.

Of the "principal categories" discussed in the second half of the book, the business letter-heading was the most ubiquitous and most fundamental item. and the one most thoroughly affected by standardization. One could also see it as the ground on which business efficiency and design-aesthetics most clearly come together, or confront each other. First, the DIN standard fixed the size of the letter-heading as its A4 format $(297 \times 210 \mathrm{~mm})$ : the size that has become standard throughout the metric world (that is, everywhere except North America). And then, within the sheet, fields were established for the disposition of categories of information, as well as a minimum lefthand margin and positions for fold-marks and punch-holes.

As Tschichold makes clear, he did not think that a DIN standard was any guarantee of design quality. His view of the design of publications issued by the Deutscher Normenausschuss, and the examples that it had designed to illustrate its standards, was that they were "of astonishingly low quality" (p. 112, footnote). Tschichold developed, here and elsewhere in his writings of this time, a set of terms that he deployed to brilliant pedagogic effect. ${ }^{35}$ The possibilities form a spectrum from "unstandardized and undesigned" (the example on p. 121), "standardized but undesigned" (p. 123). "unstandardized but designed" (p. 113), through to the most desired state of "standardized and designed" (p. 120). In particular, the contrast between the examples facing each other on pages 120 and 121 shows the order and clarity that Tschichold - more than the other New Typographers - was by then able to achieve.

\section{LETTERFORMS}

"Among all the types that are available, the so-called 'Grotesque' (sanserif) ... is the only one in spiritual accordance with our time" (p. 73). Here, as throughout the book. Tschichold gives his argument the largest world-historical resonance. But, by comparison with his arguments con-

\section{xxwiti}


cerning all the other aspects of typography, it does seem that his attitudes to letterforms, and to typefaces in particular, were especially informed by the rationale of the Zeitgeist and by larger, not strictly typographic, considerations. In the German-speaking world, more than in other cultures, the style of letterform could be a highly charged issue. A glance at the diagram on page 75 confirms this. In Germany, to set text in some variety of blackletter script was still normal in the 1920s; though, since the reforming movement of the previous few years, it was also on the wane. Tschichold's discussion of the typefaces of current German newspapers (p. 212) is interesting evidence of this state of affairs: so too is his addendum note (p. 233) reporting that the Berliner Tageblatt was the first large German newspaper to go over entirely to roman (Antiqua) typefaces. One need only consider the subsequent history of letterforms in Germany, during the 1930 s and 1940s, to realize that Tschichold's highly charged arguments were of a piece with the raised emotions of his times. ${ }^{36}$

On the question of letterforms, the demands made by German New Typography, as expressed in this book, might be seen in this way: roman as a minimum demand: sanserif (as a special category of "roman") as the preferred choice; and then a reformed orthography and alphabet as the maximum demand (discussed in the next section). Having asserted the appropriateness - the necessity - of sanserif as the letterform of the modern world. Tschichold then makes the realistic qualifications that were always a feature of his writing. even at its most utopian. Thus: currently available sanserifs were not really satisfactory, and the recently designed ones, such as Erbar and Kabel, show the idiosyncrasies of the "artist's typefaces": Futura, designed by Paul Renner, is better in this respect: but the satisfactory sanserif will probably come only through a process of collective and anonymous design (p. 74). It is interesting to note Tschichold's recommendation of certain anonymously designed (seriffed) roman typefaces. Thus. he mentions Sorbonne. Nordische Antiqua, and Französische Antiqua - all now forgotten and out of use - as to be preferred over other available sanserifs and romans, for setting continuous text. "They are easily legible: they are also above all in a technical sense useful and free from personal idiosyncrasies - in the best sense of the word, uninteresting" (p. 76). This pleasure in the unassuming and the modestly efficient, coupled with a hefty dislike of the self-indulgently "artistic," was a persistent motive throughout Tschichold's career.

As Tschichold explains (p. 75), in choosing a typeface for this book, he was constrained by what the printer had available. One may guess that the 
printer (the "Buchdruckwerkstätte $\mathrm{GmbH}$ ") was simply the printing office of the Bildungsverband. ${ }^{37}$ The typeface used was an "Akzidenz Grotesk": a "jobbing sanserif," designed anonymously, probably in the 1900s. For the reasons already outlined, he would have preferred this over any of the recently designed sanserifs, which (in the case of Futura) would hardly have been available for purchase at the time the book was being set. On the evidence of a contemporary catalogue, there could be several possibilities for a more exact identification of the typeface used. ${ }^{38}$ But, for the purpose of characterizing Tschichold's preferences, "Akzidenz Grotesk" in a light (as against medium or regular) weight is sufficient description. He remarks ( $p .75)$ that he wanted to show that such a typeface could be easily read in continuous text - against the common assumption that sanserif is less legible or readable here than are seriffed letters. At least one reader complained about this aspect: "This thin typeface - and then printed on shiny art-paper - makes the reading of the book hardly the pleasant exercise that Tschichold assumes it will be." 39 Tschichold was at least aware that readability was a prime issue, if one that was complicated by the other issues with which he was then concerned.

In a later reference to the setting of his own book (p. 227). Tschichold mentions the constraint of having a sufficient quantity of type with which to set a long text: something that could militate against setting a book in sanserif. It is clear that he was then still working in conditions where hand-setting of books was common or even usual: in book printing, at least, if not throughout the industry. ${ }^{40}$ In this light, it may not be so surprising that the mechanization of text-setting is not discussed or even mentioned in this book. Here, as elsewhere in architecture and design. modernist theory - which would have preferred machine-setting, as more in tune with the spirit of the age - could only run ahead of the real conditions of production. 41

\section{ORTHOGRAPHY}

For Tschichold, as for some of his visionary artist-designer colleagues, the question of letterforms could not be separated from orthography and a reform of the systems of written and printed language. And, as with letterforms and the debate over black letter, there was a specifically Germanlanguage dimension to the matter. He argues for a revised orthography that would be phonetically exact and consistent, and for a single set of letters. The argument is shot through with the rhetoric of modernism: for economy 
of means, consistency, speed of action, greater comprehensibility, and (perhaps implicitly) abolition of hierarchy. It is part of the reform of life, and nothing to do with mere fashion. Tschichold insists (the advertisement from Vogue set in lower case, reproduced on page 80 , sums up the empty fashionable manner).

In comparison with other language communities, orthographic reform was more of a live issue in the German-language context, in which capital letters were (and still are) conventionally used for the first letter of every noun. So the proposal to abolish capitals would have had greater shock effect in German. As Tschichold points out with some evident pleasure (p. 81 ), the best source for these radical ideas was a book written, not by a philologist or artist, but by an engineer. This was Walter Porstmann, already introduced here as a principal proponent of paper-size standardization, whose Sprache und Schrift was published by the Verein Deutscher Ingenieure in 1920. Porstmann's book is a quite extensive (108 pages, A4 format) compendium of argument and evidence on these themes, put into the narrowly utilitarian typographic dress that was habitual in publications from standardization bodies. As with paper-size standardization, this reform was proposed by Porstmann and the Deutscher Normenausschuss merely on grounds of efficiency and commercial expediency; the argument was then translated into a new sphere of visual and also social-political consciousness by the artist-designers who took it up.'"

Tschichold's advocacy of lower-case typography (Kleinschreibung) and a reformed orthography was first made in his elementare typographie manifesto of 1925: "An extraordinary economy would be achieved through the exclusive use of small letters - the elimination of all capital letters; a form of writing and setting that is recommended as a new script by all innovators in the field." 42 He then refers to Porstmann's Sprache und Schrift, and hints at the need to consider phonetics. The book was in the air at that time. Thus, in a letter to Tschichold in response to elementare typographie, El Lissitzky asked: "What sort of book is this Sprache und Schrift (Porstmann)? If it is good, can you get it for me, I will send money at once."43 Several of the artist-designer New Typographers took up the cause of orthographic reform: El Lissitzky and László Moholy-Nagy had already published generalized proclamations, but now these demands began to be worked into visual form. In 1925, the Bauhaus went "lower case" in its publications and internal communications, as part of a general shift towards a more industrially oriented modernism (summed up in the move from Weimar to Dessau).44 The three-part statement at the foot of the school's letter- 
heading (reproduced here on p. 124) would have given any correspondent the theoretical justification, complete with reference to Porstmann's book. Moholy-Nagy argued for "opto-phonetic" research towards a new script: Herbert Bayer published his essay towards a new alphabet; Joost Schmidt and Josef Albers used the notion of a simplified alphabet in teaching projects. In 1927. Kurt Schwitters - who as a visually conscious "sound-poet" had an obvious interest in the matter - published his "Systemschrift." 45 And in 1930. Tschichold too published an essay towards a reformed script, thus going some way towards fulfilling his own postulation (pp. 83-84) of a truly consistent and "economic" system. 46

The debate over orthography was not confined to the artist-designers, as can be seen in the pages of Typographische Mitteilungen, particularly from around 1928. The issue of August 1929 contained a number of articles on the theme and an editorial affirming support for lower-case typography. One culmination came in 1931. A special issue in May included an editorial, which is unusual in its emphasis on the political aura of lower-case typography (as bringing equality of status to letters). The printers were asked to read the articles carefully, and then to vote on whether they preferred (1) capitals at the start of sentences and for proper names only. (2) complete abolition of capital letters, (3) retention of present German orthography. The August issue reported the result: 53.5 per cent of the 26.876 votes were for the first option, 23.5 per cent for the second, and 23.0 per cent for the third. Around this time the debate over letterforms (black letter or roman) was coming to the fore again, and orthographic reform was pushed aside. Despite the result of this poll, Typographische Mitteilungen never adopted the moderate reform of the first option.

\section{PHOTOGRAPHY}

"As a consequence of the purity of its appearance and of the mechanical production process, photography is becoming the obvious means of visual representation in our time" (p. 88). Photography was an essential, constituent part of the New Typography, as Tschichold's consideration of it in this book shows. His discussions here makes some defense of photography against the accusation that it cannot be "art" (but. given the modern movement's attack on conventional notions of art, such a defense would be rather beside the point). An issue of more immediate moment was the disapproval of photography within printing, particularly "fine printing" and traditionalist book typography, which were then still devoted to handproduced means of generating images. Here. Tschichold is unapologetic:

\section{xxxil}


"We today have recognized photography as an essential typographic tool of the present. We find its addition to the means of typographic expression an enrichment, and see in photography exactly the factor that distinguishes our typography from everything that went before" (p. 92).

One should point out that there is a distinction to be made between photography used as a means of reproduction in the processes of printing and the printed reproduction of photographic prints. Tschichold's discussion, like many others, blurs the two phenomena. He is essentially concerned with the second - the evident presence of photography in printing - and not with the first phenomenon, which includes fundamental but hardly visible innovations like photolithographic printing and (then still hardly developed) photocomposition of text.

The argument for the photographic image paralleled that for sanserif (equally disliked by traditionalists): and the two elements could then be joined in "typo-photo." $\mathbf{4 7}$ This - the conjunction or juxtaposition of text and image - was really the defining method of New Typography in using images, and can be regarded as one of its lasting legacies, now so generally employed as to be unnoticed or called simply "graphic design." But, at this point, the issues surrounding photography were still contested. Through the common ground of typo-photo. New Typography spilled over easily into the parallel "new photography" movement. Thus Tschichold was one of a three-person executive committee for the Deutscher Werkbund's seminal "Film und Foto" exhibition, held in Stuttgart in 1929, and for which he also designed stationery. He was also the designer and joint author, with his friend Franz Roh, of the book that arose from this exhibition, fotoauge. ${ }^{48}$

\section{THE NEW BOOK}

The last of the "principal categories of typography" to be considered is the book: apparently the stronghold of traditionalists, but also the subject of some recent visionary speculation. Tschichold describes and reproduces examples of work that breaks with conventional procedures of book design. Behind such work lay the hypothesis that the form of the book should adapt to new needs and new patterns of life (more active, more visual, a quicker tempo). Postulations of this kind were in the air then, and have resurfaced in various guises since. Certainly books were then becoming more visual. The integration of pictures with text was becoming technically easier, with developments in lithographic and gravure printing. The "integrated book," with pictures placed beside the text relating to them, would 
also have been encouraged by the change of attitudes that New Typography brought about. This meant a disruption of "classical" ideas of separation and balance, towards a view of the book as a usable carrier of information.

Tschichold touches on the social and material context of book production. showing again his deep dislike of bibliophile attitudes (pp. 224, 227). One can add something to his remarks here, and also suggest that "new books" were then being produced in Germany, as well as being postulated in visionary theory. From the mid-1920s a number of book clubs began to publish books that aimed to provide their members with affordable, wellproduced, intelligent books. which were broadly progressive or socialist in content. ${ }^{49}$ The Bildungsverband's own Büchergilde Gutenberg and the Bücherkreis, which had affiliations with the SPD (the German socialdemocratic party), were both launched in 1925, and may be mentioned here especially for the typographic quality of their books. Tschichold designed one book for the Büchergilde Gutenberg, the Fahrten- und Abenteuerbuch by Colin Ross (reproduced on p. 223, with his annoyed remark about a change in its design), which can be taken as typical of early exercises in New Typography in this medium: headings in bold sanserif type, ranged to the left; photographs as illustration, printed on the same paper as the text (though not on the same pages): page numbers set in bold sanserif, larger in size than the text typeface (an unostentatious seriffed type). Later, from around 1930. Tschichold worked (as a freelance) for the Bücherkreis: he was responsible for the design of most of their books, as well as for their leaflets, stationery, and graphic symbol. These books show New Typography developing a subtler approach - headings are now in smaller sizes, there is some integration of pictures with text - and at least one of these books was entirely set in Futura.

Tschichold's realism, in this his most extreme book, is evident on the closing page of its text. His remarks about typefaces for books take into account availability, readability, and content. Finally, qualifying any absolute commitment to the DIN sizes, he suggests that books to be read while held in the hand will have to be put into formats other than these. In a moment of seemingly absurd but delightful precision, he suggests that at least the height of such books could be standardized at $176 \mathrm{~mm}$ : in fact the height of the B5 format (see the diagram on the facing page). 50 The tension between the wish to stick to agreed norms and the urge to design for human ease is resolved in this aside: "e.g. $176 \mathrm{~mm}$ depth for novels."

\section{xxoxiv}




\section{AFTER DIE NEUE TYPOGRAPHIE}

The publication of the book came at a moment when the New Typography movement was consolidating, after a time of discovery and invention; and the book itself would have played some part in the process of growing selfawareness and self-confidence among those involved. Tschichold continued to teach at the Meisterschule at Munich, although evidently restless in this position. $51 \mathrm{He}$ and other New Typographers continued to write and publish, though the difficulty of doing so - in a time of recession, growing unemployment, and political violence - can be seen and felt in the thinning issues of the journals of those years. Typographische Mitteilungen is a case in point: its editorial comment increasingly takes on political concerns, so that the "struggle" for the New Typography is indivisible from the political struggle.

Tschichold became, from 1928 and up to the end of his life, a remarkably prolific author of articles about typography in the specialist press: a bibliography lists around 175 such pieces, over almost fifty years. 52 Three further books, or independent titles, on typography by him were published in Germany, before his emigration in 1933. Eine Stunde Druckgestaltung appeared in 1930: one might explicate the title as "one hour for most of what you need to know about the subject of designing for print." Tschichold used the occasion to publish perhaps his most compact and compelling statement of the principles of New Typography, as a preface to an anthology of examples, which follows the themes and methods of the second half of the present book. ${ }^{53}$ Schriftschreiben für Setzer (1931) is a brief (32 pages, landscape A5 format) introduction to letterforms and to the practice of formal writing for printing-compositors. Typografische Entwurfstechnik (1932) is another short (24 pages, A4 format) manual, also directed at compositors and typographers. It explains techniques of drawing printingtypefaces on layouts - a topic largely passed over in the literature of practical typography - as well as providing design instruction and useful information on the DIN formats. These works assume and demonstrate the integration of New Typography into the everyday practice of printing: as if the revolutionaries had captured the key centres of control, and it now remained for their ideas to be spread calmly into the lifeblood of the whole system.

Some of the other literature of New Typography from these years should be mentioned, as a reminder that the ideas of the movement emanated from more than one source. Paul Renner's Mechanisierte Grafik (1931) makes an 
interesting contrast with Die neue Typographie. A work of theory, rather than a practical manual, its discussion is consistently general, as if from a level above that of the pointed specificity of Tschichold's writing (even at its most theoretical). ${ }^{54}$ While of approximately the same size and number of pages, the design of the two books is markedly different. Although set in a sanserif (his own Futura), Renner's book still feels conservative: text set in quite a large type-size and well leaded, printed on an uncoated cartridge paper, while the pictures are printed on an art-paper section at the end. By comparison, in content and in its own form. Die neue Typographie is more severe and more committed to a new vision.

Closer in spirit to Tschichold's book was Gefesselter Blick (which might be translated as "captured glance"), a sequence of "25 short monographs" edited by Heinz and Bodo Rasch. ${ }^{55}$ This book contains short introductory considerations of "the image" and "letters," followed by its main content of the monographs: a short biography of the designer, a statement (signed with a facsimile signature), and examples of work. Among the twenty-five participants, the Ring "neue werbegestalter" designers were all represented, and the book and an accompanying exhibition in Stuttgart were arranged with the collaboration of the Ring. Tschichold's statement of position was very brief: "In my graphic design, I attempt to achieve maximum purposefulness [Zweckmäßigkeit] and to unite the individual component parts harmonically: to design [zu gestalten]." By comparison with Die neue Typographie, in which Tschichold is the sole mediator and reporter, Gefesselter Blick, in its anthology or group character, is an even clearer indication of New Typography as a movement.

The Bildungsverband der Deutschen Buchdrucker published another handbook in 1929: Grundsätzliches zur neuen Typographie by Philipp Albinus. This short work ( 52 pages, just smaller than $A 5$ format) points up, by contrast, the qualities of Die neue Typographie. The book includes some ideological references, as well as instruction about design, but Albinus (a printer) was without the formal sensitivity and verbal eloquence that marked Tschichoid. The same can be said of the book Modern Typography and Layout (1929) by the American printer Douglas McMurtrie: an early. stray treatment of the subject from the English-language world.

\section{TSCHICHOLD'S EMIGRATION}

Early in March 1933. Tschichold was taken into "protective custody" by the recently installed National Socialist authorities in Germany. ${ }^{\mathbf{5 6}} \mathrm{He}$ was included in the crack-down, soon after Hitler's seizure of power, against those termed "cultural bolsheviks" and other opponents of the regime.

\section{xxxvi}


There would, for example, have been enough evidence of this "cultural bolshevism" within the pages of Die neue Typographie, if the new authorities had chosen to look through its pages. And in his case, as already indicated. perhaps unremarkable socially progressive modernist views had been coloured by a specific affiliation to Slavic culture. Tschichold was held for about six weeks, during which time he was dismissed from his post at the Meisterschule. The conditions of detention were lenient enough for him to design a book-binding for the Insel-Verlag, before being released under a general amnesty of such prisoners. Jan and Edith Tschichold, with their young son, then immediately made plans to emigrate to Switzerland. Tschichold secured a part-time job with the printer and publisher Benno Schwabe at Basel, and some teaching work at the Gewerbeschule there. and moved with his wife and child in July 1933.

Since the late 1920s. Tschichold's typography had begun to show a greater subtlety and sophistication: a development that was continued and accentuated in his first years in Switzerland. The prime document from this period was his book Typographische Gestaltung, published in Basel by Schwabe (1935), and in foreign-language editions: Danish, Swedish (both 1937), and Dutch (1938).57 The book follows the structure of Die neue Typographie: a historical review, a statement of the aims of New Typography, and then detailed consideration of the elements of typography. ending with a section on "the new book." But the language is more considered, with much less invocation of the "spirit of the time" and with more emphasis on the details of typographic design. This commitment to details - always present in his work - would have been helped in its development through his experience with the printer-publisher Schwabe, where the work would have encompassed editorial, printing-technical, and design considerations. ${ }^{\mathbf{5 8}}$ The shift away from ideological argument can be seen as a response to "the times," which were indeed very bad. The political storms and ruptures had, as one small side effect, destroyed the confidence with which Tschichold could publish lists of like-minded designers in Europe: their addresses had now changed or were uncertain and contact with them had ceased. The New Typography as a "movement" had come to an end.

Tschichold was unusual among emigrés from Germany in the way in which he was (after some years of insecurity) able to settle and integrate into Swiss society: in 1942, he was granted citizen's rights in Basel; and it was remarked that he learned to speak flawless Swiss-German dialect.59 The trauma of 1933, the slide of world politics towards war, the new context of a politically neutral and culturally more stable society, his growing and eventually almost exclusive concentration on book design: these are among 
the factors that can be mentioned in Tschichold's turn to a traditional approach to typography. Another factor that has been mentioned is his contact with the "new traditionalist" typographers in England (Stanley Morison and Oliver Simon, most notably), whom he would have met personally on a visit to London in 1937, when he addressed the Double Crown Club in an after-dinner speech. ${ }^{60}$ The change may be dated (on Tschichold's own account) to around 1938: from which time he worked almost exclusively in the symmetrical mode. with typefaces deriving from pre-industrial models (though in versions made for machine composition): and from being a tireless promoter of modernism in typography, he became one of its most acute and sometimes acid critics. ${ }^{61}$

\section{AGAINST THE NEW TYPOGRAPHY}

The first published statement of position came in 1946, in a reply to Max Bill, who had made a barely veiled attack on his change of position. 62 Tschichold's argument was notable for its moral and political dimension, especially for its contemplation of the seemingly inevitable loss of human values in industrialized labour. A key passage (set in italics) read:

Its [the New Typography's] intolerant attitude certainly corresponds in particular to the German inclination to the absolute: its military will-to-order and its claim to sole power correspond to those fearful components of German-ness which unleashed Hitier's rule and the Second World War. ${ }^{63}$

This was uttered in the heat of a polemical exchange, and in the immediate aftermath of the war.

Tschichold maintained this political-philosophical charge against the New Typography for the rest of his life, though later he put it in less intense language. He also came to emphasize a set of more purely typographic objections to modernism in this field. Thus in an exchange with the modernist "Swiss typographers" (as they are now termed) who came to prominence in the late 1950s, he made a number of powerful criticisms of the New Typography (or, more exactly. the typography that it had by then led to in Switzerland). ${ }^{64}$ Among these objections were: that it was essentially limited to publicity work and to the subject matter of the modern world, and could not deal with the complexities of book design: that in relying on sanserif, it used an unbeautiful letterform that could not be read easily as continuous text; that the DIN paper-sizes were inappropriate for many purposes, books above all; that it tended to adopt a rigid formalism that failed to articulate the meaning of the text; that it lacked grace.

\section{xxoxvifi}




\section{DIE NEUE TYPOGRAPHIE IN ITS CONTEXT}

Tschichold was by this time speaking from vast experience, particularly as a book designer, and in a context - the German-speaking world in the years of the Federal Republic's "economic miracle" - very different from the fresh and uncertain years of Weimar Germany, in which the New Typography had come into existence. The gap between the two moments contains a world war, extraordinary devastation and reconstruction, and. although only thirty years in extent, it covers a profound change in the quality of culture and society. It was perhaps inevitable and understandable that the later Tschichold should have wanted to modify and sometimes forbid the republication of the documents of his New Typography.

In an obvious and fundamental sense, he was still the same author: although his views had changed, he had the same traits of a polemical manner and a passion for detail, the same wish to point out faults, which he did for anyone whom he saw making errors, including his younger self. Although the change of approach surprised contemporaries, the continuities of Tschichold's career may now be seen to outweigh the breaks. Even at the time of its publication. his old teacher at Dresden. Heinrich Wieynck, observed that Die neue Typographie was a marker in a development that was not over yet: he wondered if this development could "perhaps in the future restore Johannes to a place of honour." 85 This was a remarkable perception, although faise in the sense that the "Johannes" who returned was not the Johannes of Leipzig or Dresden in 1921, but the "Jan" of Basel in the late 1930s (and subsequently). In other words: a typographer who had incorporated the experiences of his times and contexts, and whose work evolved into something fresh. The context of the present edition of Die neue Typographie is different from any that its author knew. Equally, the present edition will have an afterlife in contexts that we cannot imagine. But we do know something of the first context of this book, five thousand copies of which were printed and published in Berlin in the summer of 1928.

\section{ACKNOWLEDGMENT}

For help with research and in the writing of this introduction, I am grateful for help and advice given by the following people: András Furész, Richard Hollis, James Mosley, and the Resource Collections staff at the Getty Center for the History of Art and the Humanities. An important collection of Tschichold papers is now in the collection of the Getty Center, but became available too late for me to consult for this work. Except where noted. translations from German texts other than the present book are by myself. 
A fairly complete edition of Tschichold's writings has been published as Schriften 1925-1974 (2 vols.; Berlin: Brinkmann \& Bose, 1991-92): references to texts reprinted there are given as "Schriften."

- Walter Benjamin. Einbahnstraße (Berlin: Rowohlt, 1928). p. 7. The translation quoted here is
very slightly modified from Edmund Jephcott's in: Walter Benjamin. One-Way Street and Other
Writings (London: NLB, 1979). p. 45 .
1. Except where noted, biographical information on Tschichold is taken from the account written
by the subject himself: "Jan Tschichold: Praeceptor Typographiae." This text was first published
under the pseudonym "Reminiscor" in Typographische Monatsblatter, vol. 91 , no. 4 (April 1972).
on the occasion of Tschichold's seventieth birthday. It was reprinted as the principal text in the
monograph whose content and design he determined, though it appeared after his death: Leben
und Werk des Typographen Jan Tschichold (Dresden: VEB Verlag der Kunst. 1977: [reset and
slightly altered edition] Munich: Saur, 1988; also Schriften 2:416-433).

2. Leben und Werk des Typographen Jan Tschichold, p. 16 (Schriften 2:422). The large claim perhaps a true one - that Tschichold was the first typographic designer is quite typical of the tone of this anonymous autobiographical Festschrift essay.

3. The book-artist (Emil Rudolf Weiss was a characteristic example) is slightingly referred to also in Die neue Typographie. Throughout his career, against figures of that kind. Tschichold worked as the capable professional who knew his job in all its details.

4. "Er... kam aufgewüh/t zurück": he came back all churned up (Leben und Werk des Typographen Jan Tschichold, p. 17: Schriften 2:423).

5. See Edith Tschichold's contribution to Philipp Luidl, ed., J.T. (Munich: Typographische Gesellschaft, 1976). pp. 29-33. Tschichold's first letter to Lissitzky. 19 January 1925 (reproduced in facsimile as a loose insert in this book). explained: "Herr Moholy-Nagy knows me very well and has given me your address. I am the only typographic Constructivist in Leipzig:"

6. Edith Tschichoid explained the changes in the names of her (then) late husband in her contribution to Luidl, J.T. When later "Iwan" proved to be an irritant to the conservative sensibilities of his colleagues and employers at Munich, Tschichold chose "Jan," as the Slav form of "Johannes." in his contribution to the same book. Werner Doede quoted a letter to him from Tschichold: ". . now 'Jan' instead of 'Ivan.' since Munich! 'Ivan' is impossible here!" (5 June 1926). These changes and their significance were noted at the time by Tschichold's teacher at Dresden. Heinrich Wieynck, in his perceptive review of Die neue Typographie in Gebrauchsgraphik (see note 16).

7. See, for example, the discussion of the Japanese newspaper in this book (p. 206), with its side-blow against "North American pseudo-culture." Unlike some of the Weimar modernists. Tschichold showed no romantic longings for America.

8. This has been reprinted twice, most accessibly by the printers and publishers H. Schmidt (Munich, 1986). elementare typographie was quite long in preparation: at Easter 1925. Tschichold wrote to Imre Kner that publication had been delayed until July (letter dated "Pfingsten 1925" in the Békés County Archive, Gyula, Hungary).

9. Tschichold himself suggested this in a letter to Piet Zwart, 31 August 1927 (Getty Center Archives. Santa Monica: file 850831 ).

10. See the account by Friedrich Friedl in his introductory text to the 1986 reprint.

11. References in correspondence from this time suggest that relations between Renner and Tschichold were quite distant and difficult. For example. Tschichold advised Piet Zwart to send examples of work to him rather than to Renner, adding "Renner still doesn't know who you are. And he is someone who has changed sides [ein Überläufer]" (14 December 1927, Getty Center Archives, Santa Monica: file 850831). Edith Tschichold described Jan Tschichold's years in Munich, including the situation at the Meisterschule, in an interview published in: Deutscher Werkbund. Die zwanziger Jahre des Deutschen Werkbunds (Gießen: Anabas, 1982), pp. 183-192. 
12. "Jan Tschichold über die neue Typographie" [signed "Neumeyer (München)"], Typographische Mitteilungen 24, no. 1 (January 1927): 22. This short précis of Tschichold's lecture suggests that most of the ideas of the book were already formulated by this time.

13. I owe this perception to Hans Schmoller. Tschichold's successor at Penguin Books, who wrote: "Whether he was the perfect teacher may be open to doubt. He rarely wanted to use the Socratic method..." (Hans Schmoller. Two Titans: Mardersteig and Tschichold [New York: The Typophiles, 1990], p. 26).

14. Letter of 15 August 1927 (Getty Center Archives, Santa Monica: file 850831).

15. The sum is in line, for example, with prices for books published by the Bildungsverband's Büchergilde Gutenberg, which were kept to a minimum level. In these years, there was some public debate over book prices in Germany, reflected in Tschichold's discussion here (pp. 230, 231): see note 48 below.

16. A thorough search has not been attempted, but two interesting reviews are: Heinrich Wieynck, "Die Wandlungen des Johannes," Gebrauchsgraphik 5, no. 12 (December 1928): 77-79: an untitled and anonymous review in bauhaus 3, no. 2 (1929): 28.

17. See, respectively, the lists in Tschichoid's Eine Stunde Druckgestaltung (Stuttgart: Wedekind, 1930) and Schriftschreiben für Setzer (Frankfurt a.M.: Klimsch, 1931).

18. Letter of 3 February 1929 (Getty Center Archives, Santa Monica: file 850831).

19. Postcard of 28 September 1930 (Getty Center Archives, Santa Monica: file 850831).

20. Letter of 16 February 1932 (Getty Center Archives. Santa Monica: file 850831 ). In the book's statement of copyright, it is stated that "all rights are reserved by the author, in particular those of translation into other languages, including Russian."

21. Letter of 29 September 1932, in: El Lissitzky, Proun und Wolkenbügel (Dresden: VEB Verlag der Kunst. 1977), p. 138.

22. A second edition, described as such on its title page, was published in 1987 by Brinkmann \& Bose in Berlin. Apart from its title and imprint pages, it is a facsimile reprint.

23. Several of these texts are available in English translation in: Uirich Conrads, ed., Programmes and Manifestoes on 20th-Century Architecture (London: Lund Humphries. 1970).

24. Quoted from the English translation by Frederick Etchells: Le Corbusier. Towards a New Architecture (London: Rodker, 1927). p. 33.

25. Notably as designer for the Bücherkreis book club (from around 1930 to 1933). which was affiliated to the German social-democratic party (SPD). Tschichold's Leben und Werk reproduces (illustration section. p. 41) a cover for the magazine Sportpolitische Rundschau (1928) that might stand for "left-wing graphic design" of this period: just as would the strikingly similar cover of a KAPD magazine Proletarier (1927), which Tschichold reproduces on p. 217 of the present book. (The KAPD was a "left-radical" grouping. which broke away from the main German communist party in 1920.] Tschichold was not the sort of person who joins political parties, but such associations were inevitable for someone of his inclinations - and in 1933 it was equally inevitable that he should have been detained as a "cultural bolshevist."

26. bauhaus 3, no. 2 (1929): 28 .

27. The most complete documentation of the Ring is provided by a set of four exhibition catalogues published under the title Typographie kann unter Umständen Kunst sein. See, in particular: Ring "neue werbegesta/ter" 1928-1933: Ein Überblick (Hannover: Sprengel Museum, 1990): Ring "neue werbegestalter"; Die Amsterdamer Ausstellung 1931 (Wiesbaden: Landesmuseum Wiesbaden, 1990). The other two catalogues, both published by the Landesmuseum Wiesbaden. document the typographic work of Kurt Schwitters and Friedrich Vordemberge-Gildewart.

28. The flavour of the Ring's activities is conveyed in the typewritten communications that Schwitters circulated. Those received by Piet Zwart are now in the Getty Center Archives. Santa Monica (file 850831), and are transcribed and published in Ring "neue werbegestalter": Die Amsterdamer Ausstellung 1931, pp. 112-116.

29. See the references in Schwitters' circulars, particularly the members' comments quoted in his "Mitteilung 19" (1928): Ring "neue werbegesta/ter": Die Amsterdamer Ausstellung 1931. pp. $115-116$. 
30. Herbert Bayer was the only "master" at the Bauhaus with a long-term commitment to typography: but - by comparison with Renner, Tschichold. or Trump. at Munich - his work showed little of the calligraphically trained and historically informed typographer's sensitivity to letterforms or to the handling of text.

31. This was one of the issues raised implicitiy by Max Bill, whose "über typografie" (see note 62 below) was set unjustified and without word-breaks; in his reply. Tschichold pointed to Eric Gill's earlier use of it and to the fact that machine-composition could handle either mode with the same facility. Another notable explorer of unjustified setting was the Dutch designer Willem Sandberg. from the 1940 s onwards.

32. Some account of the German standards bodies is available in an anniversary history: Bruno Hoim, ed., Fünfzig Jahre Deutscher Normenausschuß (Berlin: Beuth-Vertrieb. 1967).

33. On the history of Taylorism and "Scientific Management," see: Judith A. Merkle. Management and Ideology (Berkeley, Los Angeles, London: University of California Press, 1980). Of particular relevance here is Merkle's chapter on "Scientific Management and German rationalization." which outlines the "central role" of the Verein Deutscher Ingenieure in introducing Taylorism into Germany.

34. Waiter Porstmann (1886-1959) is at present an obscure figure, but he is referred to in Holm. Fünfzig Jahre Deutscher Normenausschuß, and something can be inferred also from the entries under his name in the National Union Catalog published by the Library of Congress. Washington. D.C. Ute Bruning has chased him in notes to two articles: "Zur Typografie Herbert Bayer," in Herbert Bayer: Das künstlerische Werk 1918-1938 (Bertin: Bauhaus-Archiv, 1982). pp. 118-137: "Die neue plastische Systemschrift." in "Typographie kann unter Umständen Kunst sein": Kurt Schwitters, Typographie und Werbegestaltung (Wiesbaden: Landesmuseum Wiesbaden, 1990), pp. 98-107. Ostwald published his views - and his resentment - concerning the development of the German paper-size standard in an autobiography. Lebenslinien (Berlin: Klasing. 1926-1927). 3:300-308.

35. See especially his Eine Stunde Druckgestaltung, pp. 14-25.

36. While during the $1930 \mathrm{~s}$ the National Socialists predominantly preferred black letter as the most "German" letterform, the argument was finally settled by Hitler's decree of 1941, which outlawed black letter as "Jewish." Just as the National Socialists eventually opted for neoclassical architecture, so too in typography, roman became the form that fitted the dreams of a world empire. For some detailed discussion, see: Hans Peter Willberg. "Schrift und Typografie im Dritten Reich," in Hundert Jahre Typographie: Hundert Jahre Typographische Gesellschaft München (Munich: Typographische Gesellschaft München, 1990), pp. 87-103.

37. They shared the same postal district of Berlin, SW61, and the Buchdruckwerkstätte was also the printer of books published by the Büchergilde Gutenberg (the Bildungsverband's book club). and seems to have moved with the Bildungsverband from Leipzig to Berlin

38. See the Handbuch der Schriftarten, compiled and published by Albrecht Seeman (Leipzig. 1926). Among the samples shown on p. 193, the "Grotesk P. Breite magere" from Berthold closely resembles the typeface of the book - but so do nine others.

39. Wieynck, "Die Wandlungen des Johannes," p. 77.

40. Typographische Mitteilungen published regular reports of the number of typesetting machines installed in Germany, taken from the "Jahresbericht der Zentralkommission der Maschinensetzer Deutschlands": these show a steady growth in these years, but the relation to hand-setting remains to be determined.

41. For one instance of modernist consciousness of machine composition, see note 55 below. Seven years later, in his second major book. Tschichold did devote some paragraphs to machine composition (Typographische Gestaltung [Basel: Schwabe, 1935]. pp. 32-33).

42. elementare typographie (= Typographische Mitteilungen, vol. 22, no. 10 [October 1925]). p. 198 .

43. Letter of 22 October 1925, in Lissitzky, Proun und Wolkenbügel, p. 137.

44. Much the best source here is: Gerd Fleischmann, ed., Bauhaus Typografie (Düsseidorf: Edition Marzona, 1984). All the Bauhaus material referred to in this paragraph can be found in this compendium.

45. First published in his article "Anregung zur Erlangung einer Systemschrift," i10 1. no. 8/9 (August-September 1927): 312-316. See also the article by Ute Bruning (note 34 above). 
46. In an article entitled - as if he were conscious of the by then growing list of such experiments - "noch eine neue schrift," published as an insert to Typographische Mitteilungen, vol. 27. no. 3 (March 1930).

47. This idea can be seen reflected in contemporary advertising for Futura, as the typeface "for photomontage" (for example. in Typographische Mitteilungen, April 1929).

48. Among the literature of the new photography, see: Ute Eskildsen and Jan-Christopher Horak. Film und Foto der zwanziger Jahre (Stuttgart: Württembergischer Kunstverein, 1979): David Mellor. ed., Germany: The New Photography 1927-33 (London: Arts Council of Great Britain, 1978). Roh and Tschichold's foto-auge (Stuttgart: Wedekind, 1929) was published in facsimile reprint (London: Thames \& Hudson, 1974). Another result of the Roh-Tschichold collaboration was the "Fototek" series, edited by the former, designed by the latter, and published by Klinkhardt \& Biermann in Berlin. Only volumes on Moholy-Nagy and Aenne Biermann appeared (in 1930).

49. See: Michael Bühnemann and Thomas Friedrich. "Zur Geschichte der Buchgemeinschaften der Arbeiterbewegung in der Weimarer Republik," in Wem gehört die Welt (Berlin: Neue Gesellschaft für Bildende Kunst. 1977). pp. 364-397; Horst Bunke and Hans Stern. Buchgestaltung für die Literatur der Arbeiterklasse 1918-1933 (Leipzig: Deutsche Bücherei, 1982). The Malik-Verlag has been voluminously celebrated, though it is not of special interest typographically. But see: Jo Hauberg et al., eds., Der Malik-Verlag 1916-1947: Chronik eines Verlages (Kiel: Neuer Malik-Verlag. 1986), whose thorough documentation includes (pp. 114-119) articles first published in Die Weltbühne in 1928 on the theme of the price of German books ("Ist das Deutsche Buch zu Teuer?").

50. Gerd Fleischmann in a perceptive essay ("Können Sie sich einen Flieger mit Vollbart vorstellen?'" in Beiheft: Die neue Typographie [Berlin: Brinkmann \& Bose, 1987]. pp. 33-46) also remarks on this "surprising and fascinating" detail (p. 33), but does not notice the derivation from the B5 format.

51. As is clear from his private correspondence of this time (for example in letters to Piet Zwart). There were also premature public announcements that he had taken jobs in Vienna, presumably at the Gesellschafts- und Wirtschaftsmuseum, which he visited briefly then (Typographische Mitteilungen 26. no. 9 [September 1929]: 225), and at the Höhere Graphische Fachschule in Berlin (Typographische Mitteilungen 30. no. 3 [March 1933]: 92).

52. Schriften 2:444-454.

53. "Was ist und was will die Neue Typografie," in Eine Stunde Druckgestaltung, pp. 6-8 (Schriften 1:86-94): this text was published in translation in French and English magazines, in 1930. Adolf Behne's Eine Stunde Architektur (1928) had also been published by Wedekind: suggesting an "Eine Stunde" series.

54. Renner did write a more practical counterpart to this book: Die Kunst der Typographie (Berlin: Frenzel \& Engelbrecher, 1939; rev. ed., Berlin: Druckhaus Tempelhof, 1948), but by then his already tempered modernism had tempered further.

55. Heinz and Bodo Rasch. Gefesseiter Blick: 25 kurze Monografien und Beiträge über neuer Werbegestaltung (Stuttgart: Zaugg. 1930). The Rasch brothers worked across the whole range of design disciplines and came to typography with a certain untroubled freshness. Thus in a note on the text of their book (p, 2): ". . machine composition was used as a matter of principle (nothing but lines of equal length). The lines contain 65-70 characters, in all of the three type sizes that are employed. This is the longest line that, with this typeface, is still comfortably readable."

56. Edith Tschichold described this, in the considerable detail with which traumatic events are remembered, in the interview published in: Deutscher Werkbund. Die zwanziger Jahre des Deutschen Werkbunds, especially pp. 188-191.

57. An English-language edition appeared much later (London: Faber \& Faber, 1967). It shows the awkwardness that Tschichold found in dealing with his younger self: the book's design (by Tschichold) hesitates between symmetry and asymmetry; warning footnotes are inserted by the older author; the discussion of standard paper-sizes is omitted (although these were then being introduced in Britain): and the title of Asymmetric Typography represented a revision of his earlier assumption, implied in the 1935 title, that New Typography was not a special category. but that it provided the obvious central ground for all "typographic design."

58. See the composition rules that he drew up for Benno Schwabe (Leben und Werk des Typographen Jan Tschichold, pp. 22-23: Schriften 1:202-204). This experience, as well as his 
work for the publisher Birkhäuser (from 1941), led on to his celebrated reform at Penguin Books (1947-1949). For an account of the latter, including reproduction of the Penguin composition rules, see Ruari McLean, Jan Tschichold: Typographer (London: Lund Humphries, 1975), pp. 86-104.

59. Legisiation that deterred the settlement of refugees from the occupied countries was enacted in Switzerland. which tended to be a transit zone for them. See: Helmut F. Pfanner. "The Role of Switzerland for the Refugees," in: Jarrell C. Jackman and Carla M. Borden, eds., The Muses Flee Hitler (Washington, D.C.: Smithsonian Institution Press, 1983). pp. 235-248. Max Frisch's reminiscences ("Jan Tschichold als Nachbar") in Luidl. J.T., pp. 81-85, give an impression of the older. Swiss Tschichold.

60. This is one of the suggestions made by G. Willem Ovink in his thorough and perceptive article "Jan Tschichold 1902-74: Versuch zu einer Bilanz seines Schaffens," Quaerendo 8, no. 3 (Summer 1978): 187-220.

61. It was around 1937 that Tschichold began to give away or sell his collection of modernist typography, which would have come to him partly through work on books such as Die neue Typographie. (Bruno Monguzzi observes this in the course of his meticulous investigation. "Piet Zwart: L'opera tipografica 1923-1933," Rassegna, no. 30 [June 1987]: 4-88; see p. 9, note 35.) But if there were emotional reasons for Tschichold to shed this material then, there may have been financial pressures too. Among institutions to acquire such work from him then were the Museum of Modern Art (New York) and the Victoria and Albert Museum (London).

61. Max Bill, "über typografie," Schweizer Graphische Mitteilungen 65, no 4 (April 1946): 193-200: Jan Tschichold. "Glaube und Wirklichkeit," Schweizer Graphische Mitteilungen 65, no. 6 (June 1946): 233-242; an English translation of Tschichold's text is given, as "Belief and Reality." in McLean. Jan Tschichold: Typographer, pp. 131-139. Bill's statement is a manifesto for his own typography. as well as an attack on Tschichold (whom he does not name).

63. Tschichold, "Glaube und Wirklichkeit," p. 234.

64. "Zur Typographie der Gegenwart," Börsenblatt für den deutschen Buchhandel 13 (1957): 1487-1490. Tschichold's article appears to have stimulated a special issue of Typographische Monatsblätter (vol. 78, no. 6/7 [June/July 1959]), with contributions from most of the leading Swiss typographers of that time, including a point-by-point response by Emil Ruder, which used the title of Tschichold's original article (pp. 363-371).

65. Wieynck, "Die Wandlungen des Johannes," p. 79. 